\section{THYMIC NEUROENDOCRINE CARCINOMA (CARCINOID): A CLINICOPATHOLOGIC STUDY OF FOURTEEN CASES}

The medical records and histologic documents of 14 patients treated at our institution for a thymic carcinoid tumor were reviewed. There were 3 women and 11 men with an age range from 35 to 71 years. One patient had a multiple endocrine neoplasia syndrome; another had a neurofibromatosis. Twelve tumors were revealed by local symptoms and two were asymptomatic. One patient had Cushing's syndrome that appeared secondarily and was related to metastases. Tumors ranged from 6 to $20 \mathrm{~cm}$ and had the characteristic histologic appearance of atypical carcinoid tumor. Immunohistochemical evaluations were done. Tumors were positive for cytokeratin (92\%), neuroendocrine markers $(\mathbf{1 0 0 \%})$, and p53 oncoprotein (29\%). S-100 protein antibody revealed numerous sustentacular cells in one case. Overall survival was $46 \%$ and $31 \%$ at 3 and 5 years, respectively. However, all patients died of the disease within 109 months as a result of local progression $(n=5)$, local relapse $(n=3)$, distant metastases $(n=8)$, or a combination of these reasons. Median survival was 71, 30, and 5 months for patients who had total resection $(n=4)$, partial resection $(n=5)$, or simple biopsy $(n=4)$, respectively $(p=0.023$ ). In conclusion, thymic carcinoid tumors can be considered thymic neuroendocrine carcinomas because of their malignant behavior and histologic appearance of atypical carcinoid tumors. Complete surgical resection offers the best hope for long-term survival. (J THORAC CARDIOvasc SuRg 1996;111:134-41)

Vincent Thomas de Montpréville, MD, a Paolo Macchiarini, MD, ${ }^{\mathrm{b}}$ and Elisabeth Dulmet, MD, ${ }^{\mathrm{a}}$ Le Plessis-Robinson, France
$\mathrm{M}$ ediastinal or thymic carcinoid tumors are extremely rare and only a few small series have been reported in the literature. ${ }^{1-7}$ Among malignant epithelial tumors of the thymus, these carcinoid tumors are presently sharply separated not only from thymomas but also from thymic carcinomas. ${ }^{8,9}$ To provide more diagnostic, prognostic, and histologic data about this unusual neoplasm and to discuss the nosologic features of thymic carcinoid tumors and their relations with thymic carcinomas, we present the cases of 14 patients who underwent operation at our institution.

From the Departments of Pathology and Thoracic and Vascular Surgery and Heart-Lung Transplantation, ${ }^{\mathrm{b}}$ Marie-Lannelongue Surgical Center (Université Paris-Sud), Le PlessisRobinson, France.

Received for publication Dec. 28, 1994.

Accepted for publication May 2, 1995.

Address for reprints: V. Thomas de Montpréville, Service d'Anatomie Pathologique, Centre Chirurgical Marie Lannelongue, 133 Avenue de la Résistance, 92350 Le PlessisRobinson, France.

Copyright (C) 1996 by Mosby-Year Book, Inc.

$0022-5223 / 96 \$ 5.00+0 \quad \mathbf{1 2 / 1 / 6 5 9 6 8}$

\section{Material and methods}

Between 1960 and 1990, 17 patients underwent operation for a mediastinal carcinoid tumor at our institution. Clinical data were obtained from patients' records and follow-up information from the referring physician. Three cases were excluded from this study; two were considered metastatic lesions from an associated large bronchial atypical carcinoid tumor and a pancreatic neuroendocrine carcinoma. A third case was excluded because of insufficient histologic material. The 14 remaining cases, which form the basis of the current study, presented as primary mediastinal neoplasms. A primary lung tumor was ruled out by bronchoscopy $(n=8)$ and radiographs, tomographs, or computed tomographic scan of the chest. Tumor size was determined from the surgical specimen or, when the tumor was not resected, from imaging studies of the chest. Tumor location was assessed from these imaging studies and from surgical report.

Tissue for light microscopy and immunochemistry was fixed in buffered 10\% formaldehyde and embedded in paraffin. All cases were stained with hematoxylin and eosin and Grimelius stains. A mean of five paraffin blocks was available for each case. Atypical carcinoid tumor was defined according to the criteria used for bronchopulmonary neuroendocrine tumors. ${ }^{10}$ Immunohistochemical study was done with LSAB Kit peroxidase (Dako, Trappes, France). The following primary antibodies were used with the indicated dilutions: rabbit anti-human 
Volume 111, Number 1

Table I. Initial clinical and radiologic features, treatment, and follow-up

\begin{tabular}{|c|c|c|c|c|c|c|c|c|}
\hline $\begin{array}{l}\text { Patient } \\
\text { no. }\end{array}$ & $\begin{array}{l}\text { Age, } \\
\text { sex }\end{array}$ & $\begin{array}{l}\text { First symptom, } \\
\text { duration }\end{array}$ & $\begin{array}{l}\text { Clinical findings } \\
\text { at diagnosis }\end{array}$ & $\begin{array}{l}\text { Tumor size }(\mathrm{cm}) \\
\text { and location }\end{array}$ & $\begin{array}{c}\text { Initial } \\
\text { operation }\end{array}$ & $\begin{array}{c}\text { Postoperative } \\
\text { treatment }\end{array}$ & $\begin{array}{c}\text { Relapse } \\
\text { and metastasis }\end{array}$ & $\begin{array}{l}\text { Total survival } \\
\text { after diagnosis }\end{array}$ \\
\hline 1 & $53, \mathrm{M}$ & $\begin{array}{l}\text { Chest pain, } \\
6 \text { mo }\end{array}$ & Normal & $\begin{array}{l}7 \times 5.5 \times 3 \text {, } \\
\text { sup., ant., and left }\end{array}$ & Total Tx & No & $\begin{array}{l}\text { Local } \mathrm{R} \text { at } 25 \mathrm{mo} \\
\text { treated by } \\
\mathrm{RT} \text { and } \mathrm{CT}\end{array}$ & $\begin{array}{l}79 \text { mo with } \\
\text { progression } \\
\text { of local } R\end{array}$ \\
\hline 2 & $66, \mathrm{M}$ & None & Normal & $\begin{array}{l}12 \times 10 \times 6 \text {, sup. } \\
\text { ant., and left }\end{array}$ & Total Tx & RT (60 Gy) & Local $\mathrm{R}$ at $68 \mathrm{mo}$ & $71 \mathrm{mo}$ \\
\hline 3 & $71, \mathrm{M}$ & $\begin{array}{l}\text { Pain, cough, } \\
5 \text { mo }\end{array}$ & Normal & $\begin{array}{l}13 \phi \text {, sup., ant., } \\
\text { and left }\end{array}$ & Subtotal $\mathrm{Tx}$ & $\mathrm{RT}$ and $\mathrm{CT}$ & $\begin{array}{l}\text { Symptomatic } \\
\text { treatment for } \\
\text { vertebral met. } \\
\text { at } 49 \text { mo }\end{array}$ & $\begin{array}{l}56 \text { mo, suicide, } \\
\text { progression } \\
\text { of met. }\end{array}$ \\
\hline 4 & $54, \mathrm{M}$ & $\begin{array}{l}\text { Dyspnea, } \\
6 \text { mo }\end{array}$ & $\begin{array}{l}\text { Severe dyspnea, } \\
\text { asthenia }\end{array}$ & $\begin{array}{l}20 \phi \text {, all ant. me- } \\
\text { diastinum }\end{array}$ & Debulking & RT & Local progression & $6 \mathrm{mo}$ \\
\hline 5 & $49, \mathrm{~F}$ & None & Normal & $\begin{array}{c}6 \times 4 \times 4, \text { middle } \\
\text { mediastinum }\end{array}$ & $\begin{array}{l}\text { Total } \mathrm{Tx} \\
\text { and } 5 \mathrm{~mm} \\
\text { lung } \mathrm{Mx}\end{array}$ & No & $\begin{array}{l}\text { Vertebral Mx at } \\
60 \text { mo, brain } \\
\text { Mx at } 84 \text { mo }\end{array}$ & $\begin{array}{l}109 \text { mo with } \\
\text { new brain } \\
\text { met. }\end{array}$ \\
\hline 6 & $56, \mathrm{~F}$ & $\begin{array}{l}\text { Chest pain, } \\
3 \text { mo }\end{array}$ & $\begin{array}{l}\text { Dyspnea, left RP, } \\
\text { asthenia }\end{array}$ & $\begin{array}{l}7 \phi \text {, middle medi- } \\
\text { astinum }\end{array}$ & Biopsy & No (refused) & Not known & Not known \\
\hline 7 & $55, \mathrm{M}$ & Not known & $\begin{array}{l}\text { SVC syndrome, } \\
\text { pleural effusion }\end{array}$ & $\begin{array}{l}\text { Not known, }{ }^{*} \text { ant. } \\
\text { and sup. }\end{array}$ & Biopsy & Symptomatic & Local progression & 1 mo \\
\hline 8 & $39, \mathrm{M}$ & $\begin{array}{l}\text { Chest pain, } \\
1 \mathrm{yr}\end{array}$ & Weight loss & $\begin{array}{l}12 \phi \text {, all sup. me- } \\
\text { diastinum }\end{array}$ & Biopsy & RT & $\begin{array}{l}\text { Osseous and } \\
\text { brain met. }\end{array}$ & $5 \mathrm{mo}$ \\
\hline 9 & $58, \mathrm{M}$ & $\begin{array}{l}\text { Pain, dyspnea, } \\
5 \mathrm{mo}\end{array}$ & Asthenia, dyspnea & $\begin{array}{l}10 \times 10 \times 6 \text {, ant. } \\
\text { and sup. }\end{array}$ & Subtotal $\mathrm{Tx}$ & $\begin{array}{l}\text { RT (50 Gy) } \\
\text { and CT }\end{array}$ & $\begin{array}{l}\text { Left pleural car- } \\
\text { cinosis at } \\
16 \mathrm{mo}\end{array}$ & $20 \mathrm{mo}$ \\
\hline 10 & $38, \mathrm{M}$ & $\begin{array}{l}\text { Chest pain, } \\
1 \mathrm{yr}\end{array}$ & $\begin{array}{l}\text { Dyspnea, weight } \\
\text { loss }\end{array}$ & $\begin{array}{l}10 \phi \text {, ant. and } \\
\text { sup. }\end{array}$ & Subtotal Tx & Not known & $\begin{array}{l}\text { CT for local } \mathrm{R} \\
\text { and lung } \mathrm{Mx} \\
\text { at } 14 \mathrm{mo}\end{array}$ & $\begin{array}{l}64 \text { mo with } \\
\text { dissemi- } \\
\text { nated dis- } \\
\text { ease }\end{array}$ \\
\hline 11 & $35, \mathrm{M}$ & $\begin{array}{l}\text { Chest pain, } \\
3 \text { mo }\end{array}$ & $\begin{array}{l}\text { SVC syndrome, } \\
\text { dysphonia }\end{array}$ & $\begin{array}{l}8 \times 7 \times 4 \text {, ant. } \\
\text { and sup. }\end{array}$ & Subtotal Tx & $\mathrm{RT} \dagger$ and $\mathrm{CT}$ & $\begin{array}{l}\text { CT for cervical } \\
\mathrm{LN} \text { met. at } \\
30 \text { mo }\end{array}$ & $\begin{array}{l}40 \text { mo with } \\
\text { progression } \\
\text { of LN met. }\end{array}$ \\
\hline 12 & $68, \mathrm{M}$ & $\begin{array}{l}\text { SVC syn- } \\
\text { drome, } 2 \\
\text { mo }\end{array}$ & SVC syndrome & $\begin{array}{l}8 \times 7 \times 3 \text {, ant., } \\
\text { sup., and left }\end{array}$ & Total Tx & RT (60 Gy) & $\begin{array}{l}\text { RT for cervical } \\
\text { LN and verte- } \\
\text { bral met. at } \\
18 \text { mo }\end{array}$ & $\begin{array}{l}36 \text { mo with } \\
\text { Cushing's } \\
\text { syndrome }\end{array}$ \\
\hline 13 & $47, \mathrm{M}$ & $\begin{array}{l}\text { Dysphonia, } \\
1 \mathrm{yr}\end{array}$ & $\begin{array}{l}\text { Left RP, SVC } \\
\text { syndrome, sub- } \\
\text { clavicular mass }\end{array}$ & $8 \phi$, ant. and sup. & $\begin{array}{l}\text { Biopsy (cer- } \\
\text { vical LN } \\
\text { met.) }\end{array}$ & Not known & Not known & $10 \mathrm{mo}$ \\
\hline 14 & $55, \mathrm{M}$ & $\begin{array}{l}\text { Chest pain, } \\
1 \text { mo }\end{array}$ & $\begin{array}{l}\text { SVC syndrome, } \\
\text { dysphonia }\end{array}$ & $\begin{array}{l}10.5 \times 9.5 \times 9 \text {, } \\
\text { ant., sup., and left }\end{array}$ & Biopsy & $\begin{array}{l}\mathrm{RT}(40 \mathrm{~Gy}) \\
\text { and CT }\end{array}$ & Local progression & $14 \mathrm{mo}$ \\
\hline
\end{tabular}

$M$, Male; $F$, female; sup., superior; ant., anterior; $T x$, tumor resection; $R$, relapse; $R T$, radiation therapy; $C T$, chemotherapy; met., metastasis; $M x$, metastasis resection; $R P$, recurrent paralysis; $S V C$, superior vena cava; $L N$, lymph node.

* Massive right pleural effusion.

$\$ 40$ Gy before operation and 20 Gy after operation.

neuron-specific enolase (Dako, 1/50), monoclonal mouse anti-human chromogranin $\mathrm{A}$ (Dako, 1/40), rabbit anti-cow S-100 (Dako, 1/200), monoclonal mouse antikeratin (KL1, Dako $1 / 50$ ), monoclonal mouse anti-human p53 protein (Dako, 1/25), monoclonal mouse anti-human macrophage CD68 (KP1, Dako, 1/50), rabbit anti-synthetic human adrenocorticotropic hormone (ACTH) 1-24 (Dako, 1/200), rabbit anti-bombesin (Euromedex, Schiltigheim, France, 1/1000), polyclonal rabbit anti-glucagon (Unipath, Dardilly, France; prediluted), rabbit anti-insulin (Unipath, prediluted), rabbit anti-pancreatic polypeptide (Unipath, prediluted), and rabbit anti-somatostatin (Unipath, prediluted). Normal pancreas was used as pos- itive control for insulin, glucagon, pancreatic polypeptide, and somatostatin. Normal pituitary gland was used as positive control for ACTH and fetal lung was used for bombesin.

For statistical analysis, survival was calculated from the date of operation until death estimated with the productlimit method, and differences on its distribution were calculated with the log-rank test.

\section{Results}

Clinical and radiologic findings. Selected data at presentation are summarized in Table I. Patient 8 


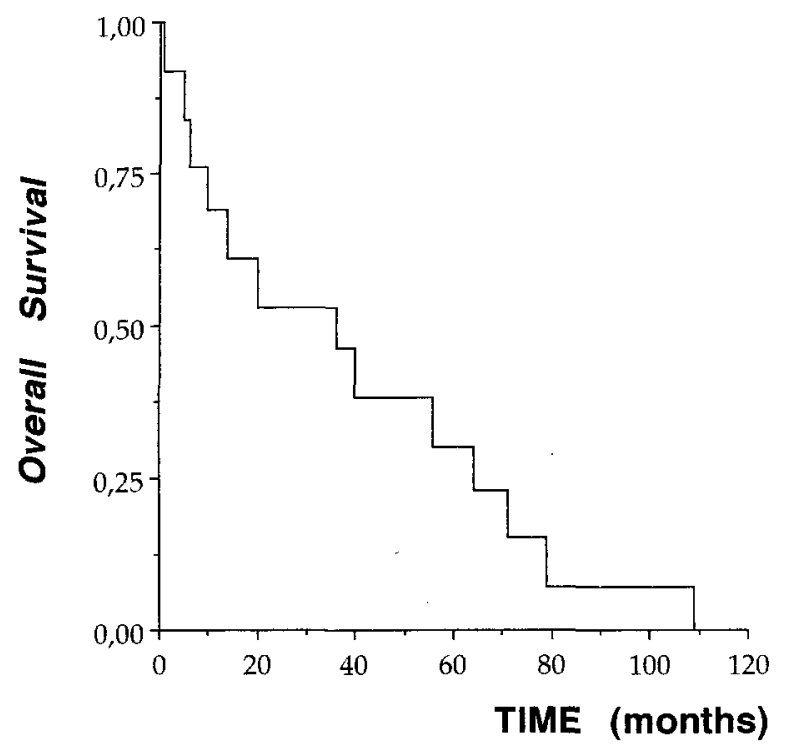

Fig. 1. Survival curve of thymic carcinoid tumors: overall survival.

had a von Recklinghausen's disease with "café au lait" spots and multiple thoracic dermal neurofibromas: symptoms similar to those of the male parent. $\mathrm{He}$ had no evidence of gastrointestinal tumor. Patient 5 had multiple endocrine neoplasia (MEN) syndrome. This patient's brother had ZollingerEllison syndrome; she herself was treated for a parathyroid adenoma 6 years after diagnosis of the mediastinal carcinoid tumor. Patient 7 had a severe chronic psychosis. At presentation, none of the patients had manifestations of abnormal secretion. In particular, none had carcinoid syndrome. Five patients were heavy smokers. All patients had abnormal findings on chest roentgenograms, and tomograms or computed tomographic scans specified size and location of the tumor. A bronchoscopy was done in eight cases and showed normal findings in two. In the six others, bronchoscopy revealed an extrinsic compression of trachea or major bronchi. Tracheobronchial biopsy provided no tumoral material.

Laboratory findings. Serum carcinoembryonic antigen level was normal in six cases and elevated in case $8(24 \mathrm{ng} / \mathrm{L}$, normal $<5)$. Calcium level was normal in 11 cases. The patient with MEN syndrome had hypercalcemia $(2.7 \mathrm{mmol} / \mathrm{L}$, normal $<2.6)$ with elevated alkaline phosphatase levels ( $166 \mathrm{IU} / \mathrm{L}$, normal $<90$ ). These abnormalities were probably related to the parathyroid adenoma later discovered. Patient 10 also had hypercalcemia $(3.16 \mathrm{mmol} / \mathrm{L}$, normal <2.6) but normal alkaline phosphatase levels. No patient underwent further investigation in the search for hyperparathyroidism at that time. Serum ionic concentrations were normal in all cases and no patient had hypokalemia that could indicate a possible hypercortisolism. Urinary $5-\mathrm{OH}-$ indoleacetic acid value was normal in the three tested cases. The patient with neurofibromatosis had a normal urinary vanillylmandelic acid level (20 $\mu \mathrm{mol}$ in 24 hours, normal $<30$ ).

Treatment and follow-up data (Table I). Tumoral resections were often extended to invaded adjacent structures: pericardium in five cases, lung (wedge resection) in two cases, innominate vein in one case, and vena cava in two cases. Invaded thymus could be identified in three cases. Subtotal resection was done in four cases in which tumoral tissue was left by one phrenic nerve when the two were invaded ( 3 cases), in the trachea ( 1 case), in the left carotid artery ( 1 case), and in the subclavian artery (1 case). Adjuvant treatments were not standardized. Three years after initial diagnosis, Cushing's syndrome developed in patient 12 with high and irregular ACTH serum levels. There was no sign of mediastinal tumoral relapse and Cushing's syndrome was related to a T12 vertebral metastasis. Overall survival was $46 \%$ and $31 \%$ at 3 and 5 years, respectively; however, all patients died of the disease within 109 months with a median survival of 28 months (Fig. 1). Death was related to local progression ( 5 cases), local relapse ( 3 cases), and distant metastases ( 8 cases). Median survival was 71,30 , and 5 months for patients who had total resection $(n=4)$, partial resection $(n=5)$, or simple biopsy $(n=4)$, respectively $(p=0.023)$ (Fig. 2).

Pathologic findings. All tumors demonstrated the characteristic neuroendocrine architecture of carcinoid tumors, often with palisading or rosette patterns. In 12 cases, the tumor contained irregular areas of necrosis, sometimes with foci of dystrophic calcification. The stroma was usually scant and fibrovascular, but in six cases it was focally fibrous and in case 11 (treated by radiation) the tumor had a dense hyalin fibrous stroma (Fig. 3). Tumoral cells were of large size and regular. Their nucleus was oval to round with finely granular chromatin. Cytoplasm was eosinophilic or pale. These cells had a polygonal shape but were fusiform in case 5 associated with MEN syndrome (Fig. 4) and in a small area in case 2 . There was no small cell component. Mitotic figures could be observed in all cases but were never greater than 10 per 10 high-power fields 


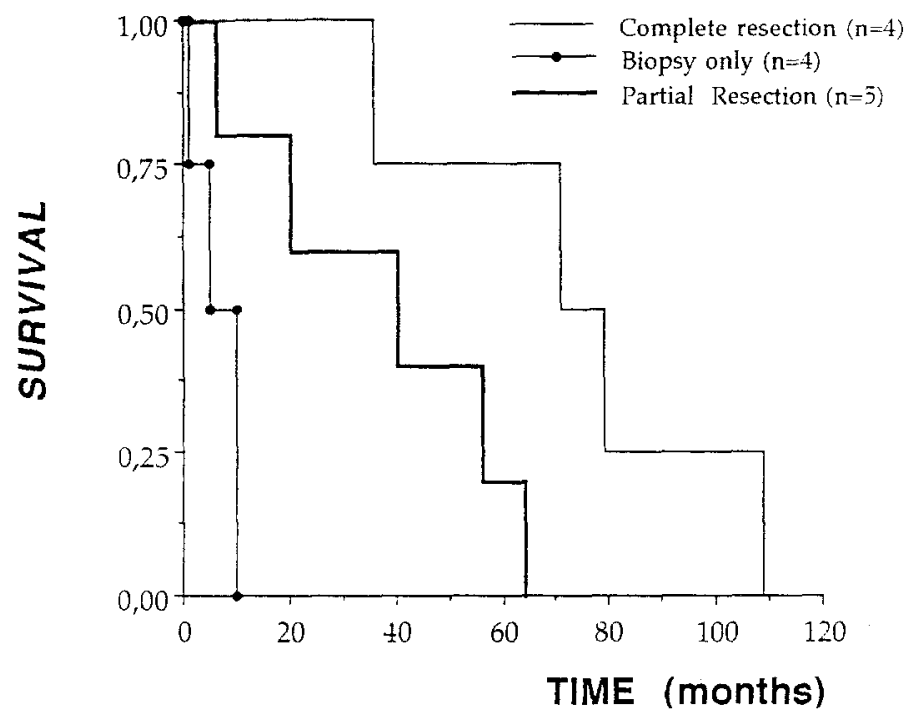

Fig. 2. Survival curve of thymic carcinoid tumors: survival according to type of operation $(p=0.023)$.

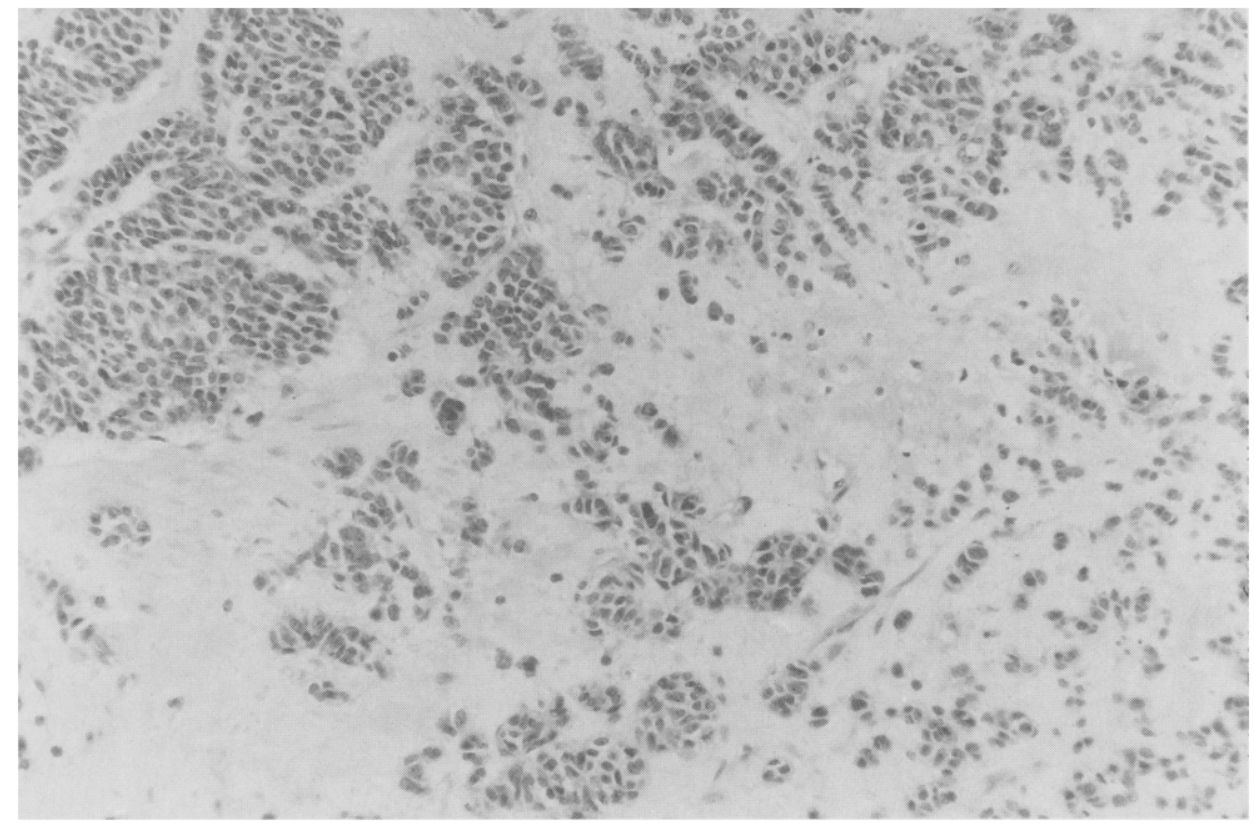

Fig. 3. Case 11. Nonsterilized thymic carcinoid tumor displaying abundant hyalin fibrous stroma after preoperative radiation therapy.

(Fig. 4). Because of necrosis and mitotic activity, all cases were classified as atypical carcinoid tumors.

Tumors were partially encapsulated. A pseudocapsule wạs sometimes identified as a thickened fibrous mediastinal pleura. Tumoral infiltration of adipose tissue was observed in 5 of the 10 resection specimens and was associated with tumoral lymphangitis in two cases.
Histochemical and immunohistochemical findings (Table II). All tumors expressed at least two of the three neuroendocrine markers used in this evaluation. In case 3 , anti-S-100 protein antibody revealed numerous cells with morphologic features of the sustentacular cells seen in paraganglioma (Fig. 5). These cells did not express the CD68 histiocytic marker. Otherwise, tumoral cells were S-100 protein 


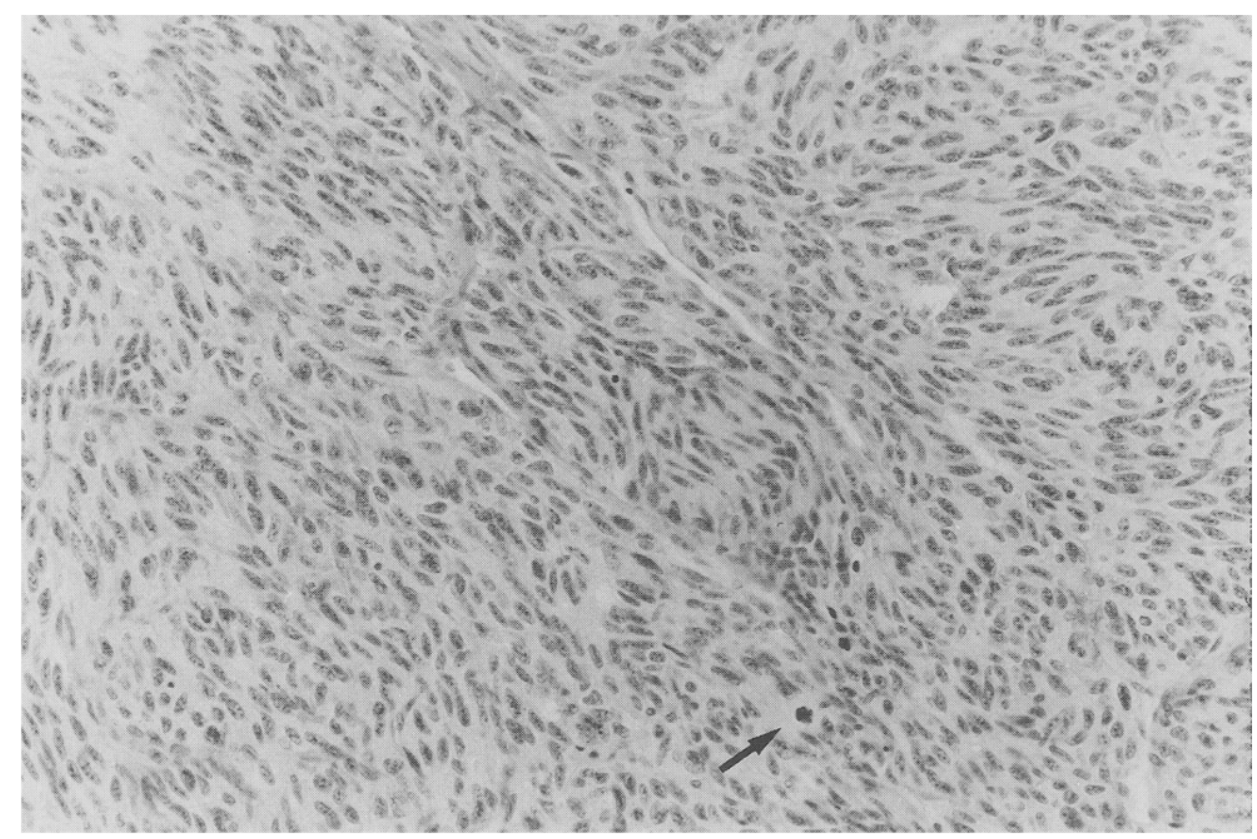

Fig. 4. Case 5 (associated with MEN syndrome). Thymic carcinoid tumor made up of spindle cells. This morphologic appearance can be confused with that of spindle cell thymoma, but lack of lymphoid component and immunohistochemical data permitted diagnosis. Mitotic feature is indicated with arrow.

Table II. Grimelius stain and immunohistochemical findings

\begin{tabular}{|c|c|c|c|c|c|c|c|c|c|c|c|c|c|c|}
\hline & \multicolumn{14}{|c|}{ Case } \\
\hline & 1 & 2 & 3 & 4 & 5 & 6 & 7 & 8 & 9 & 10 & 11 & 12 & 13 & 14 \\
\hline Grimelius & - & + & - & + & - & - & + & - & + & + & + & + & - & + \\
\hline Cytokeratin & + & + & + & + & + & - & + & nd & + & + & + & + & + & + \\
\hline NSE & + & + & + & + & + & + & + & + & + & + & + & + & + & + \\
\hline Chromogranin & + & + & - & + & + & + & - & - & + & - & + & + & - & - \\
\hline Protein S-100 & - & - & $+*$ & - & - & - & - & - & - & - & - & - & - & - \\
\hline $\mathrm{p} 53$ & + & - & - & - & + & + & + & - & - & - & - & - & - & - \\
\hline
\end{tabular}

$n d$, Not done; NSE, neuron-specific enolase.

*Sustentacular cells.

negative in all cases. Cytokeratin was strongly expressed in 10 cases including the one with sustentacular cells, weakly in case 12 , and focally in case 5 with fusiform cells. Antibody to p53 stained strongly most of the tumoral cell nuclei in case 7 and weakly few of these nuclei in three other cases. No secretion product was detected by immunohistochemistry. In the patient in whom Cushing's syndrome later developed, testing for $\mathrm{ACTH}$ was negative in the primitive tumor.

\section{Discussion}

The observations made in this study provide evidence that thymic carcinoid tumors (1) may present with a variety of clinical onsets, (2) behave as malignant tumors, (3) have a prognosis related to the radicalness of the surgical resection, and (4) have a distinctive histologic and immunohistologic appearance. These neoplasms can either be asymptomatic, associated with symptoms related to local growth, or part of a MEN syndrome and can produce endocrinopathy, ${ }^{1-9}$ especially Cushing's syndrome. ${ }^{11,12}$ The peculiarity of our case with Cushing's syndrome was that the endocrinopathy was not present at the time of diagnosis and appeared only in the late phase of the disease. MEN syndrome often comprises hyperparathyroidism, as in our case. ${ }^{13} \mathrm{~A}$ tumor developed in one of our patients in association with neurofibromatosis, another systemic disease involving the neuroendocrine system. This is an unusual event because in this condition, carcinoid tumors are rare and almost exclusively gastrointestinal. $^{14}$

Our study confirms the malignant behavior and the poor prognosis of thymic carcinoid tumors. In three previously published series, 4 of $7,{ }^{5} 7$ of $8,{ }^{6}$ and 5 of $8^{7}$ cases were reported as having locally invasive lesions and only 4 of our 14 cases could be totally resected. Relapse occurred in 3 of our 8 patients who underwent surgical resection. Distant metastases occurred in 7 of our patients and in 11 of 15,211 


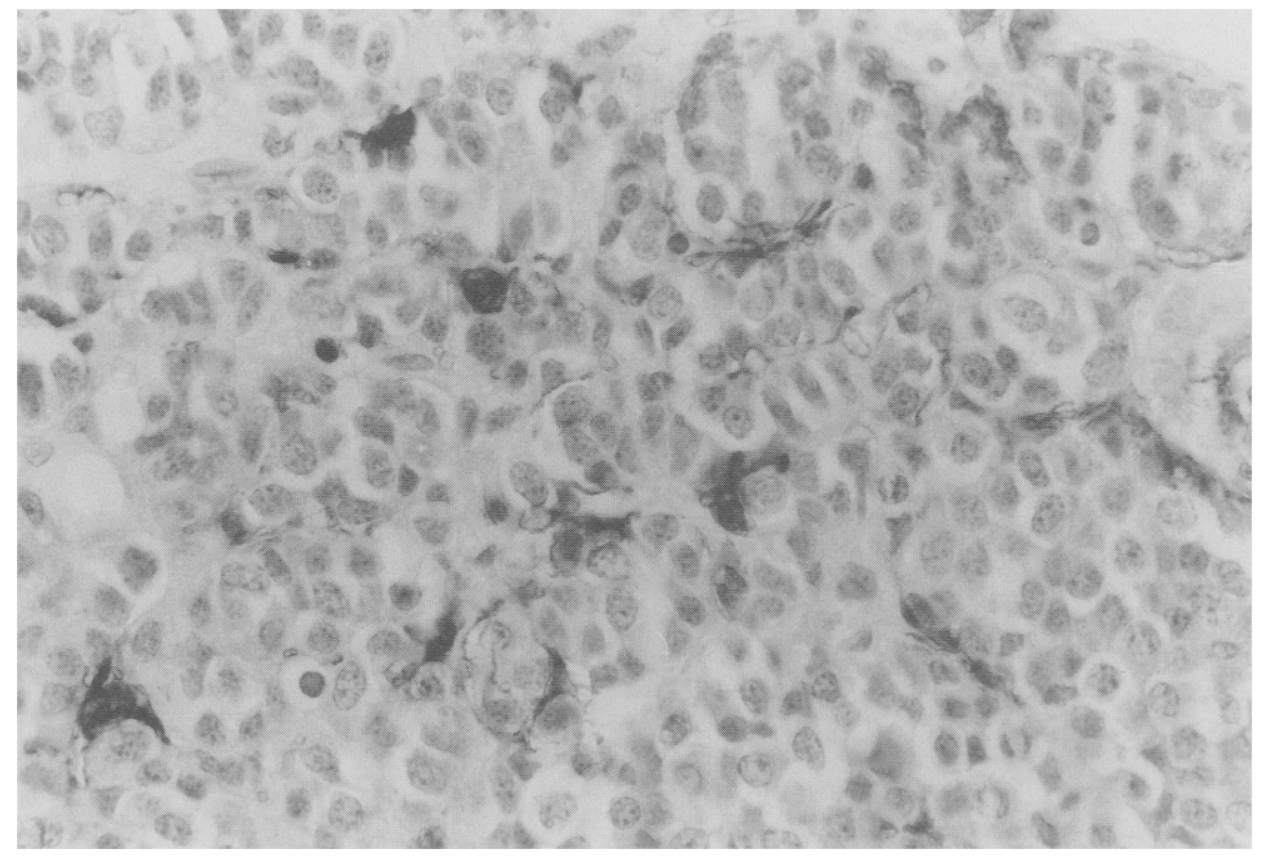

Fig. 5. Case 3. Sustentacular cells revealed by anti-S-100 protein in thymic carcinoid tumor.

of $12,,^{3}$ and 7 of $8^{6}$ patients in three other series. Only 6 of 44 cases from four series, ${ }^{2,5,7}$ including ours, have had a protracted course with a survival of more than 8 years. Median survival of 28 months in our series is in line with that reported by others., ${ }^{2,5}$ Operation is the most effective treatment ${ }^{5}$ and complete resection offers the best hope for long-term survival.

Histologic diagnosis of mediastinal carcinoid tumor is facilitated by recognition of its characteristic morphologic features. Areas of necrosis, sometimes calcified, are usual features. ${ }^{9}$ Our case with hyalin fibrous stroma was interesting in that the tumor had been radiated with $40 \mathrm{~Gy}$ and was absolutely not sterilized. In the current series and in our recent study of 98 mediastinal germ cell tumors, ${ }^{15}$ we did not encounter carcinoid tumors arising in a germ cell neoplasm like the one previously reported. ${ }^{16}$ Our case with sustentacular cells is a variant not previously reported. Such "paraganglioid" tumors generally account for a variable percentage of bronchial and gastrointestinal carcinoid tumors and have no other relevant biologic significance. ${ }^{17} \mathrm{ACTH}$ is the neuropeptide most commonly detected in thymic carcinoid tumors, ${ }^{2}$ but other secretory products, which do not usually correspond to manifestation of clinical symptoms, ${ }^{4}$ have also been detected. ${ }^{3,4}$ Our immunohistochemical neuropeptide search had negative results. The p53 nuclear oncoprotein was detected in $45 \%$ of 22 pulmonary atypical carcinoid tumors but not in any of 15 typical carcinoids. ${ }^{18}$ In our current series, 4 (29\%) of 14 tumors were found to express p53. This expression had no prognostic value because two of these patients had a rapid fatal outcome and another had the longest survival.

The thymus is considered the principal origin for primary mediastinal carcinoid tumors. ${ }^{9}$ These thymic tumors can be differentiated from other mediastinal neuroendocrine neoplasms. ${ }^{19}$ A metastasis especially from a bronchopulmonary carcinoid tumor must be clinically formally excluded. Mediastinal parathyroid adenomas are not exceptional, ${ }^{19}$ but only the rare and exceptionally nonsecreting mediastinal parathyroid carcinoma can be considered in the differential diagnosis of thymic carcinoid tumor with malignant behavior. Mediastinal paragangli$\mathrm{oma}^{20}$ theoretically can be distinguished from carcinoid tumors by its constant lack of immunoreactivity for cytokeratin. Nonneuroendocrine mediastinal neoplasms, which can histologically be confused with carcinoid tumors, are infrequent thymomas without any lymphoid component. Immunohistochemical negativity for neuroendocrine markers can permit diagnosis.

Our study confirms that thymic carcinoid tumors represent a specific entity. This entity is usually 
separated from the other malignant epithelial thymic tumors, namely, thymomas and thymic carcinomas. However, several elements suggest that thymic carcinoid tumors may be compared with the group of thymic carcinomas. This comparison is based on the following observations. First, thymic carcinomas are rare and not associated with immunologic disorders such as myasthenia gravis. These carcinomas have a propensity to produce lymph-node and extrathoracic metastases. ${ }^{21-23}$ Such clinical features are shared with thymic carcinoid tumors and clearly distinguish these tumors from the more common and less aggressive thymomas. Furthermore, the prognosis in patients with thymic carcinoid tumors is close to the survival rate (33.3\% at 5 years) reported for thymic carcinomas. ${ }^{22}$ Second, all our 14 cases and all the 8 cases in a recent detailed pathologic series $^{7}$ were considered atypical carcinoid tumors. Typical carcinoid tumors of the thymus are exceptional. ${ }^{7}$ In the lung, the term atypical carcinoid tumor is used as synonymous with well-differentiated neuroendocrine carcinoma. ${ }^{10}$ The term carcinoma is suitable for thymic carcinoid tumors and is a better term to indicate an epithelial neoplasm with malignant behavior than carcinoid, which in some locations such as lung ${ }^{10}$ corresponds to a benign or a low aggressive tumor. Third, there is no histologic evidence to exclude a well-differentiated neuroendocrine carcinoma in the heterogeneous group of thymic carcinomas. Obvious features of cytologic atypia are usually required for this diagnosis ${ }^{21}$ but several thymic carcinomas, such as mucoepidermoid carcinoma, are of a low-grade histologic type. ${ }^{22}$ The group of thymic carcinomas also includes small cell carcinoma, ${ }^{22}$ which is another neuroendocrine neoplasm. Fourth, recognition of a carcinoid component in rare thymic carcinomas confirms a link between these two entities. ${ }^{24,25}$

In light of these arguments, inclusion of thymic carcinoid tumors in the group of thymic carcinomas, as has already been suggested by a recent surgical series of thymic carcinomas including two carcinoid tumors, ${ }^{23}$ appears justified. Therefore a thymic carcinoid tumor should be considered, as has already been proposed, a thymic carcinoma of a carcinoid $\operatorname{type}^{26}$ or, rather, as a thymic well-differentiated neuroendocrine carcinoma. This would permit a more comprehensive classification of malignant thymic epithelial neoplasm by distinguishing all thymic carcinomas (neuroendocrine and others) from thymomas.
We thank the following physicians for providing follow-up information about their patients: Dr. J. P. Bataini, Institut Curie, Paris; Dr. N. Breteau, Hôpital de la Source, Orléans; Dr. C. Brochard, Centre Hospitalier de Longjumeau; Dr. C. D. Guyonnaud, Hôpital J. Monod, Le Havre; Dr. P. Rampert, Centre R. Huguenin, St. Cloud; and Dr. P. Ruffié, Institut G. Roussy, KremelinBicètre. We also gratefully acknowledge Dr. Charles Brink for reviewing the manuscript, Miss Danielle Gentric (Service d'anatomie pathologique, Pr. P. Bruneval, Hôpital Broussais, Paris) and Miss Sylvie Planté for technical assistance, Mrs. Marie-Laure Legenty for secretarial assistance, and Mr. Denis Pétraz for photographic work.

\section{REFERENCES}

1. Wick MR, Scott RE, Li CY, Carney JA. Carcinoid tumor of the thymus: a clinicopathologic report of seven cases with a review of the literature. Mayo Clin Proc 1980;55:246-54.

2. Wick MR, Bernatz PE, Carney JA, Brown LR. Primary mediastinal carcinoid tumors. Am J Surg Pathol 1982;6:195-205.

3. Wick MR, Scheithauer BW. Thymic carcinoid: a histologic, immunohistochemical, and ultrastructural study of 12 cases. Cancer 1984;53:475-84.

4. Herbst WM, Kummer W, Hofmann W, Otto H, Heym C. Carcinoid tumors of the thymus: an immunohistochemical study. Cancer 1987;60:2465-70.

5. Economopoulos GC, Lewis JW, Lee MW, Silverman NA. Carcinoid tumors of the thymus. Ann Thorac Surg 1990;50:58-61.

6. Wang DY, Chang DB, Kou SH, et al. Carcinoid tumors of the thymus. Thorax 1994;49:357-60.

7. Valli M, Fabris GA, Dewar A, et al. Atypical carcinoid tumour of the thymus: a study of eight cases. Histopathology 1994;24:371-75.

8. Rosai J, Levine GD. Tumors of the thymus. In: Firminger $\mathrm{HI}$, ed. Atlas of tumor pathology, 2nd series, fascicle 13. Washington, D.C.: Armed Forces Institute of Pathology, 1976:167-81.

9. Verley JM, Hollmann KH. Tumours of the mediastinum. In: Gresham GA, ed. Current histopathology. Vol. 19. London: Kluwer Academic, 1992:102-8.

10. Travis WD, Linnoila RI, Tsokos MG, et al. Neuroendocrine tumors of the lung with proposed criteria for large-cell neuroendocrine carcinoma: an ultrastructural, immunohistochemical, and flow cytometric study of 35 cases. Am J Surg Pathol 1991;15:529-53.

11. Pass HI, Doppman JL, Nieman L, et al. Management of the ectopic ACTH syndrome due to thoracic carcinoids. Ann Thorac Surg 1990;50:52-7.

12. Gartner LA, Voorhess ML. Adrenocorticotropic hormone-producing thymic carcinoid in a teenager. Cancer 1993;71:106-11.

13. Zieger MA, Swartz SE, MacGillivray DC, Linnoila I, Shakir M. Thymic carcinoid in association with MEN syndromes. Am Surg 1992;58:430-4. 
Volume 111, Number 1

14. Hough DR, Chan A, Davidson H. Von Recklinghausen's disease associated with gastrointestinal carcinoid tumors. Cancer 1983;51:2206-8.

15. Dulmet EM, Macchiarini P, Suc B, Verley JM. Germ cell tumors of the mediastinum: a 30-year experience. Cancer 1993;72:1894-901.

16. Warren JS, Yum MN. Carcinoid tumor arising in a treated primary germ cell tumor of the mediastinum. South Med J 1987;80:259-61.

17. Barbareschi M, Frogo B, Mosca L, Carboni N. Bronchial carcinoids with S-100 positive sustentacular cells: a comparative study with gastrointestinal carcinoids, pheochromocytomas and paragangliomas. Pathol Res Pract 1990;186:212-22.

18. Roncalli M, Doglioni C, Springall DR, et al. Abnormal p53 expression in lung neuroendocrine tumors: diagnostic and prognostic implications. Diagn $\mathrm{Mol}$ Pathol 1992;1:129-35.

19. Wick MR, Rosai J. Neuroendocrine neoplasms of the mediastinum. Semin Diagn Pathol 1991;8:35-51.

20. Moran CA, Suster S, Fishback N, Koss MN. Mediastinal paragangliomas: a clinicopathologic and immu- nohistochemical study of 16 cases. Cancer 1993;72: 2358-64.

21. Truong LD, Mody DR, Cagle PT, Jackson-York GL, Schwartz MR, Wheeler TM. Thymic carcinoma: a clinicopathologic study of 13 cases. Am J Surg Pathol 1990;14:151-66.

22. Suster S, Rosai J. Thymic carcinoma: a clinicopathologic study of 60 cases. Cancer 1991;67:1025-32.

23. Hsu CP, Chen CY, Chen CL, et al. Thymic carcinoma: ten years' experience in twenty patients. J Thorac Cardiovasc Surg 1994;107:615-20.

24. Sensaki K, Aida S, Takagi K, et al. Coexisting undifferentiated thymic carcinoma and thymic carcinoid tumor. Respiration 1993;60:427-9.

25. Paties C, Zangrandi A, Vassallo G, Rindi G, Solcia E. Multidirectional carcinoma of the thymus with neuroendocrine and sarcomatoid components and carcinoid syndrome. Pathol Res Pract 1991;187: 170-7.

26. Kirchner T, Müller-Hermelink HK. New approaches to the diagnosis of thymic epithelial tumors. Prog Surg Pathol 1989;10:167-89.

\section{Bound volumes available to subscribers}

Bound volumes of THE Journal of THORacic And CARDiovascular Surgery are available to subscribers (only) for the 1996 issues from the Publisher, at a cost of $\$ 100.50$ for domestic, $\$ 128.94$ for Canadian, and $\$ 120.50$ for international subscribers for Vol. 111 (January-June) and Vol. 112 (July-December). Shipping charges are included. Each bound volume contains a subject and author index and all advertising is removed. Copies are shipped within 60 days after publication of the last issue of the volume. The binding is durable buckram with the JouRnal name, volume number, and year stamped in gold on the spine. Payment must accompany all orders. Contact Mosby-Year Book, Inc., Subscription Services, 11830 Westline Industrial Drive, St. Louis, Missouri 63146-3318, USA; phone 800-453-4351 or 314-453-4351.

Subscriptions must be in force to quallify. Bound volumes are not available in place of a regular JourNaL subscription. 